\title{
Factors affecting the nature of alliance governance and competitiveness
}

\author{
Viput Ongsakul \\ Dean, School of Business \\ NIDA Business School \\ National Institute of Development Administration \\ Bangkok, Thailand \\ Nakul Parameswar \\ Indian Institute of Management Jammu \\ Jammu and Kashmir, India \\ Sanjay Dhir \\ Department of Management Studies \\ Indian Institute of Technology (IIT) Delhi \\ Hauz Khas, New Delhi, India
}

\section{Keywords}

Alliance governance, competitiveness, Interpretive Structural Model, technology transfer

\begin{abstract}
Coordination needs in alliances; nature of alliance governance and competitiveness of alliances are interdependent dimensions in alliances. Coordination needs are affected by technology transfer and strategic complexity which might result in alterations in the nature and background of the alliance. This research examines the effect of complexity in technological transfer, strategic specifications of the partners and prior experience of the firm in the target country on the nature of alliance governance and alliance competitiveness. Total Interpretive Structural Model (TISM) has been developed to determine the hierarchy amongst these factors. The findings provide important inferences on the factors that affect competitiveness of contractual alliances. Results suggest that nature of alliance - being contractual agreement or a joint venture influences the competitiveness of the alliance.
\end{abstract}

Corresponding author: Sanjay Dhir

Email addresses for the corresponding author: sanjaydhir.iitd@gmail.com

First submission received: 22 ${ }^{\text {nd }}$ February 2019

Revised submission received: $9^{\text {th }}$ April 2019

Accepted: 23 ${ }^{\text {rd }}$ April 2019

\section{Introduction}

Alliance governance has the options in the form of choice between contractual alliances (CA) and Joint Ventures (JV) that could determine its competitiveness (Harrigan, 1985; Doz and Hamel, 1998). These two forms lead to variations in the administration and form of governance proceedings of the collaboration (Culpan, 2009; Dhir and Mital, 2013a). Alliances help the firm gain access to knowledge and other resources while gaining legitimacy and therefore push the firm towards success (Glaister, 1998; Dhir and Mital, 2013b; Parameswar, Dhir and Ongsakul, 2018). The gravity of making these decisions has led a part of the firm's management devoting their time to making plans for future partnerships. The choice between the two forms of governance have already been studied by (Gulati and Singh, 1998; Oxley and Sampson, 2004). However, previous research has not followed a structured approach to examine the effect of factors on alliance governance system and its competitiveness. The factors affecting the choice of equity contribution by parent firms in alliance and further its impact on competitiveness. This study explores the effects of different factors in the nature of alliance i.e. contractual agreement or joint venture and on the shaping the competitiveness of the alliance. 
The paper presents the literature review of the factors and build the need to examine these factors for their influence on nature of alliance and alliance competitiveness. Next, we discuss the methodology, data and results. We then conclude with discussion, implications and future work.

\section{Governance and competitiveness in alliances}

Prior research has explored the role of diverse factors on the nature of alliance and alliance competitiveness. Doz and Hamel, 1998 highlighted that equity participation differentiates the different nature of alliance - equity and non-equity. Further, it was observed that the equity participation affects the control exercised by parent firms on their alliance (Pan and Tse, 2000; Colombo, 2003). The control level exercised by parent firms determines the kind of coordination between parent firms building trust and minimizing opportunism (Parkhe, 1993; Hennart, Dong-Jae Kim and Zeng, 1998; Madhok, 2006; Bakker and Knoben, 2014; Parameswar and Dhir, 2018a, 2019). Therefore, JV are preferred nature of alliance in comparison to other contractual agreements. Further, effect of nature of alliance on alliance competitiveness has been scantly explored in literature (Ku, Gurumurthy and Kao, 2007; Chung and Beamish, 2010).

Internalization theory proposed by Buckley and Cason, 2016 takes into account coordination cost along with appropriation concerns. It believes that control is necessary to get rid of misappropriation but is subject to the costs affiliated with coordination and competitiveness. The variation and sharing of assets, learning potential and external exchanges would affect coordination and organisational efficiency as described by Rugman and Verbeke, 2003.

Coordination from the perspective of knowledge is important because it paves the path for integration of information (Grant and Baden-Fuller, 2004; Shrotriya, Sushil and Dhir, 2017; Parameswar, Dhir and Ongsakul, 2018; Bamel, Dhir and Sushil, 2019). If we look from the viewpoint of resources equity investment provides access to complimentary resources. Resources are desired by firms when forming alliances to gain competitiveness. Alliances are also formed for the creation of product (Pfeffer and Nowak, 1976; Rothaermel and Deeds, 2004), knowledge (Kale, Dyer and Singh, 2002; Dhir, Mital and Srivastava, 2015; Rudy, Miller and Wang, 2016; Dhir and Mital, 2018) or capabilities (Colombo, 2003; Rothaermel and Deeds, 2006; Makino et al., 2007). Technical knowledge can be transferred through CA but holding an equity leads to using effort and an effortless flow of knowledge (Makino, Lau and Yeh, 2002; Dhir et al., 2019). JV along with their advantage come with its costs (Balakrishnan and Koza, 1993; Makino and Neupert, 2000). CA should be preferred unless there is an explicit need for coordination, in which case the costs may become redundant (Inkpen and Currall, 2004; Meyer et al., 2009).

\section{Literature Review and Identification of Factors}

Literature on CA has examined the role of multiple factors on the competitiveness of CA. However, in this paper we restrict the study to include 8 factors identified by practitioners (through focus group discussion) considered as important in determining the competitiveness of CA.

Industry Type

CA is imperative in any type of industry - pharmaceutical, retail, real estate, automobile, space research etc. and play an important role in the efficient functioning of the industry (Dikova and van Witteloostuijn, 2007; Morschett, Schramm-Klein and Swoboda, 2010). From another view, the type of industry in which the alliance is formed will influence the competitiveness of the CA since the dynamics of the industry will determine the role of CA and its importance. A CA in a developed and mature industry may not add much value as compared to a CA in a developing and new industry (Contractor, 1989; Wang and Blomstrom, 1992; Saggi, 2002; Dhir and Sushil, 2017; Bamel, Dhir and Sushil, 2019). The industry type will determine the need for a CA and decisions in the alliance governance thereby influencing competitiveness of CA (Kumar, 1995; Dasgupta, 2000).

\section{Strategic Specification}

Strategic specifications, the second dimension, takes into account all facets of managing and forming the alliance (Reuer and Ariño, 2007). The time frame mentioned in the contract is used as a measure of strategic specifications. An undermined time frame has a high probability of development or variations in the factor market, product or working conditions. Suppose there is an advancement in 
technology, the new machinery is one of a kind, difficult to operate and hence involves risk (Hamilton and Nickerson, 2003) and leads to strategic complexity. Such unpredictable conditions will cause scepticism and strategic reforms will have to be made. Therefore, an open-ended alliance is formed as partners cannot stipulate a time frame for the attainment of organisational objectives (Reus and Rottig, 2009). Hence strategic specifications demonstrate itself through open ended alliances.

On the other hand, alliances which have a specified lifetime show lower strategic complexity (Turowski, 2005; Dan and Zondag, 2016; Dhir and Dhir, 2018; Parameswar and Dhir, 2018b). A limited time frame will cause less uncertainty in the factor market, product or participants as any major change won't take place. Therefore, it is easier to make a contract under such steady conditions. A contract cannot accustom itself to unstable conditions. Therefore, the strategic specification of the CA will influence the competitiveness of the CA.

\section{Prior Presence of the Company}

Prior firm operations in a country influences CA formation. Alliances are a means for parent firms to venture into unchartered territory - exploration, that is new a country/market/products/services (Kogut and Singh, 1988; Madhok, 1997; Dussauge, Garrette and Mitchell, 2004). On the other hand, CA are formed to carry out expansion - exploitation, scaling up/mass production/consolidation. The first scenario shows that the partner has no knowledge about the functioning of the country market/products/services risk to forego the CA. However, in the second scenario, the parent firms have experience functioning in the country/market/products/services (Gulati, Lavie and Singh, 2009). In a way the CA is an important linchpin for the parent firms to operate and the lack of experience enhances the competitiveness of the CA as parent firms will be eager to explore with all that they possess. In the second scenario the parent firms have first-hand experience of doing business in the country/market/product/service and possess functional knowledge. Possessing this knowledge helps lower the need for CA and thereby undermine the competitiveness of the CA. Previous occupancy in the alliance country influence the parent firms' interest towards the CA and thereby influence its competitiveness.

\section{Internal Coordination and Complexity}

The emergence of complexity can be linked to the complications of managing subparts, organisational customs and standard techniques in the manufacturing of goods (Mesquita and Brush, 2008) influences the functioning of the CA. Gulati and Singh (1998) have come to the conclusion that if partners depend on each other, they will experience more complexity and coordination costs would automatically increase and undermine competitiveness. Complexity in CA depicts the adversities formed between participants while performing alliance tasks. With increased interdependence between parent firms in a CA, the need for the CA further increases and undermine competitiveness. Strategic complexity is the second element and is explicit to all interactions in the entire domain necessary to accomplish its objectives. CA vary in terms of the amount and nature of technology transfer. CA with an aim for technology transfer have purpose more important than competitiveness. The parent firms of such CA will lay emphasis on the process of technology transfer and undermine competitiveness of the CA.

\section{Number of Existing Alliance}

More the number of CA in the industry lesser will be importance for each CA (Kale and Singh, 2009; Mohr and Puck, 2013). Moreover, multiple CA by firms will not allow parent firm to focus and undertake diligent decision making. More the number of CA, lesser the likelihood of each CA being competitive (Gulati, 1998). Furthermore, being part of many CA will increase the governance cost for the firm and undermine competitiveness gained from the CA.

Nature of Alliance

CA extend from a supplier-buyer agreement to a JV and are usually categorized based on extent of equity and the nature of governance system (Harrigan, 1988; Kogut, 1988; Barringer and Harrison, 2000). As compared to other types of CA, a JV is a distinct legal entity created to fulfil a purpose (Das and Teng, 2000a; Culpan, 2009). This makes the JV operations distinct from the parent firms' operations and possess a decision-making body of its own. Such an arrangement makes the JV a distinct organization operating in 
the industry and thereby gain its own competitiveness distinct from the parent firms. JV tend to gain more competitiveness as compared to other types of CA.

\section{Methodology \\ Data and Method}

This study employs Total Interpretive Structural Modelling (TISM) (Sushil, 2017b, 2017a; Bamel, Dhir and Sushil, 2019; Hasan, Dhir and Dhir, 2019) for hierarchically depicting the role of each factor on the other and competitiveness of CA. The data is obtained by undertaking Focussed Group Discussion (FGD) with practitioners working in organizations involved in CA in India. During the FGD, emphasis was laid on making the practitioners understand the objective of the study and further gain their insights on the relationship between the factors.

TISM is an extension of Interpretive Structural Modelling (Warfield, 1974; Haleem et al., 2012; Dubey et al., 2017). An ISM interprets the links between the identified elements and the direction of the links between each pair of elements. ISM helps in identifying the contextual relationship between the identified elements of the issues and shows how the elements are related to each other (Sushil, 2017b; Shibin et al., 2018). However, ISM is not competent to explain the interpretation of the related links. Hence, TISM is used to overcome this limitation. Figure 1 depicts the different steps involved in TISM

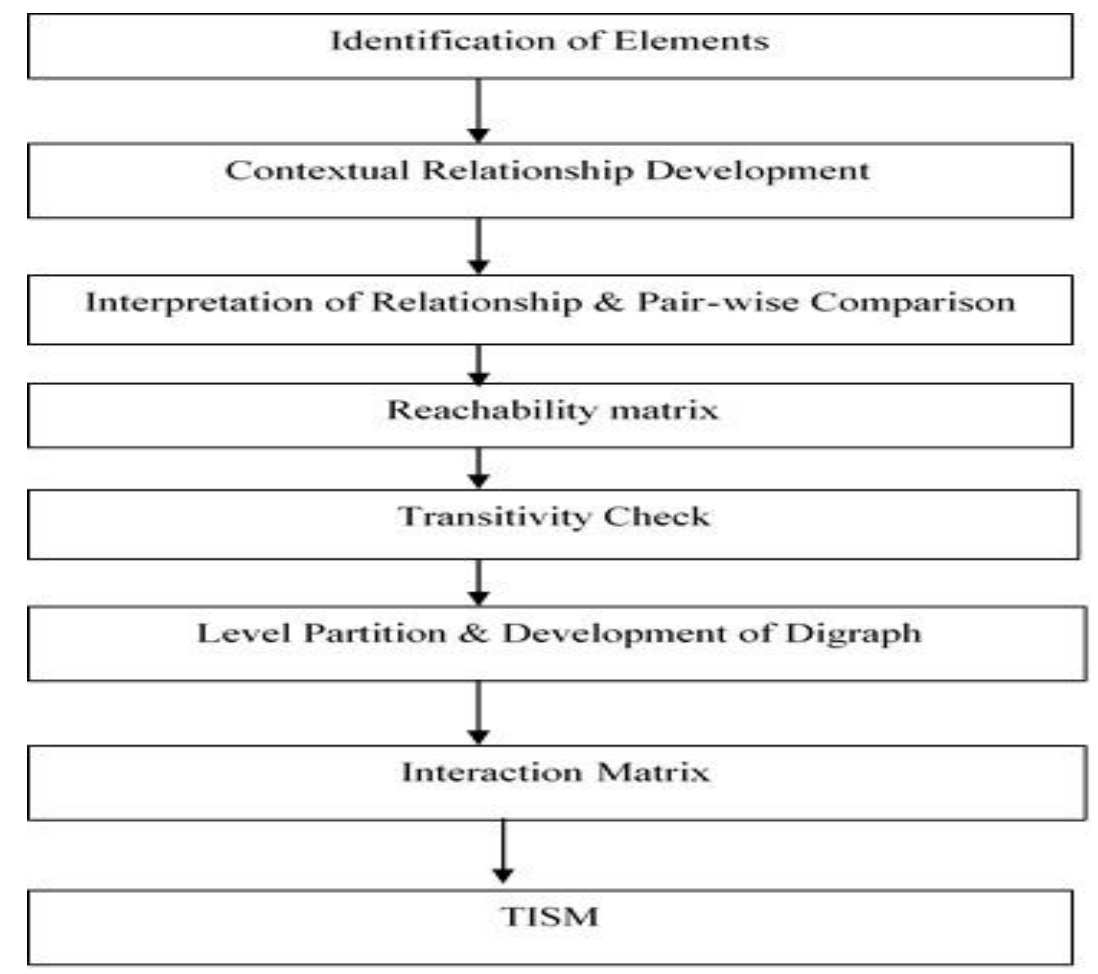

Figure 1: Steps in TISM

The process of TISM starts with the identification of elements. The second step involves the description of contextual relationships among the identified elements. The step shows that whether element A will influence the element B. This step is carried out for all the elements. The third step provided the relationship and explanation of relations between the two elements. Interpretation is performed to attain in-depth knowledge. After the interpretation, pairwise comparison is performed between the elements. All the identified elements are compared pairwise starting with the first element. The comparison between the elements is coded with Yes $(\mathrm{Y})$ or No $(\mathrm{N})$. In fourth step, reachability matrix is built. The $\mathrm{Y}$ and $\mathrm{N}$ codes are converted with 1 and 0 in the reachability matrix. Fifth step involves the transitivity check of the relations. The transitivity is checked with rule, i.e., if A-B and B-C, the A is related to $\mathrm{C}$. The link found transitive in the matrix is coded as $1^{*}$. 
After the transitivity check, the level partition is used to determine the level of the elements in the hierarchal structure. The elements having same interaction set and reachability set are positioned on the top level and then eliminated from the further set of elements until the level of each element is found. Once level is determined, hierarchy of elements is drawn, and links are used to show the relationship between the identified elements. An interaction matrix is made to provide the relevant interpretation from the knowledge base. Finally, TISM is developed by combining the digraph and interpretations by using interaction matrix. In TISM, the nodes are replaced by interpretation in the digraph.

\section{TISM for Factors influencing CA Competitiveness}

The identified elements by using literature review have been used to build the hierarchal structure by applying TISM technique. The technique helps to build the relationship among the elements. In this study, we have identified a total of eight elements in the context of alliance research based on the broad literature support and the relationship between the elements has been found. Based on the concept and technique TISM model has been build up. Table I shows the elements, contextual relationship, and interpretation between the elements.

Table 1: Elements, contextual relationship, and interpretation for identified elements

\begin{tabular}{|c|c|c|c|}
\hline $\begin{array}{c}\text { Element } \\
\text { Code }\end{array}$ & Element & Contextual relation & Interpretation \\
\hline $\mathrm{C} 1$ & Internal coordination & \multirow{8}{*}{$\begin{array}{l}\text { Element A will influence/ } \\
\text { enhance element B }\end{array}$} & \multirow{8}{*}{$\begin{array}{l}\text { How or in what way an } \\
\text { element A will } \\
\text { influence/enhance element B? }\end{array}$} \\
\hline C2 & Internal complexity & & \\
\hline C3 & Strategic Specification & & \\
\hline $\mathrm{C} 4$ & Prior presence of the company & & \\
\hline C5 & Nature of alliance & & \\
\hline C6 & Competitiveness of JV or CA & & \\
\hline C7 & No of existing alliance & & \\
\hline $\mathrm{C} 8$ & Industry type & & \\
\hline
\end{tabular}

The contextual relationship has been found was "element A will influence or enhance element B". The interpretive logic knowledge-base has been built up. Existing literatures were applied to build the reachability matrix for this study. Appendix I (See Exhibit 1) shows the interpretive logic-knowledge base for this study. The reachability matrix is made on the basis of concepts (See Exhibit 2). Also, the transitivity is checked i.e. "if element A relates to element B and element B relates to element $C$, then element $\mathrm{A}$ is transitively related to element $C^{\prime \prime}$. The reachability and antecedents of all identified elements are extended in the matirx (See Exhibit 3) from the reachability matrix.

Reachability set is comprised of an assembly of elements itself and other elements which help to understand and the antecedent set is comprised of a set of elements itself and other elements which help attaining it (Singh and Sushil, 2013; Dubey et al., 2015). The elements common in both reachability set and antecedent are allocated at the set of the intersection. The elements that are common in reachability and intersection are put into the top-most-level group (level I group). Again, these top-level elements are excluded from the next step and the process is repeated till all levels of each element are found. The digraph is built up by using the level of the elements (See Exhibit 4). This graph consists of links (both transitive and direct) between the elements which shows the relationship among the elements.

Finally, TISM structure is build up by using diagraph and information from interaction matrix (See Exhibit 5).

\section{Results and Discussion}

This study attempted to explore the effect of identified elements on the competitiveness of CA. We tried to understand influence of elements, relationship between the elements, relative importance and the 
role of elements in promoting the competitiveness and performance of Joint ventures and alliances with the help of TISM technique. ISM is not capable to analyse the mutual relationship between the elements, so we used TISM analysis for this study (Yadav, Sushil and Sagar, 2015; Sushil, 2017a). We identified eight important elements that are affecting the competitiveness of joint venture. The elements are internal complexity, internal coordination, nature of alliance, industry type, prior presence of the company, strategic specification and others mentioned above in the literature review. These identified elements were drawn from the existing literature. After identification of the elements we build up a hierarchical model of identified elements in the context of alliance or joint ventures. We have used TISM approach in order to identify the relationship and transitive links among the different elements of alliance. Data collected from Focussed Group Discussion (FGD) involving managers working in strategic alliances was utilized to build TISM.

Findings suggest that Competitiveness of CA (C6) has occupied the top most level in the TISM model. This denotes that competitiveness of the CA is the most important factor that is laid emphasis to by the practitioners who suggested that all the factors are structured in order to gain competitiveness. Internal coordination (C1) and prior presence of the company (C4) are at the second level. Internal coordination determines the level of interaction between parent firms. Prior presence of the company in the target market helps in shaping the decision of parent firms. Firms with prior presence leverage their experience in building up competitiveness in their alliance (Luo, 1997; Reuer, Zollo and Singh, 2002; Shukla and Mital, 2016; Dhir, Dhir and Samanta, 2018). The elements C1 and C4 show the importance of effective exchange of information, experience and skills for having better competitiveness of joint ventures.

Nature of alliance (C5) lies on the third level. It affects both the elements on the second level and have transitive link with competitiveness of JV. The nature of alliance shows the importance of resources, technology, management style and managerial interactions have direct effect on the internal coordination of the firms and prior presence of the company. The linkages between the factors cumulatively affect the competitiveness of the alliance.

Internal complexity (C2) and number of existing alliance (C7) lies at the fourth level and have high driving forces on other elements. C2 and C7 have also relationship with each other. These two elements are having directly or indirectly influence on $\mathrm{C} 1, \mathrm{C} 4, \mathrm{C} 5$ and finally $\mathrm{C} 6$. The Internal complexity shows the importance of willingness, trust and method of communication between partner firm and the influence on the competitiveness. Again, number of existing alliances depicts the significance of business objectives, techniques, agreements, and market access on competitiveness of the CA. Strategic specification (C3) lies at the fifth level in the hierarchical model. C3 directly influence C2 and C7. Industry type (C8) is one of the most driving forces in the present analysis. Industry type influences the all the elements directly or indirectly as it lies at the bottom in the hierarchal structure. Industry type supports the degree of organization's interdependence and competitive actions in order to select the best suitable strategy for the business. Overall, the TISM model suggests that competitiveness of CA is shaped up by other factors (Exhibit 5 depicts the final TISM model with explanations for each relationship). Amongst the other factors industry type lies at the bottom of the TISM model suggesting that it's the most important driving factors that affects all the other factors. Strategic specification, internal complexity and number of alliances appear in level 2 and 3 respectively. Nature of alliance is determined by strategic specification and internal complexity. Further, internal coordination and prior presence along with nature of alliance drives the competitiveness of the alliance.

\section{Implication of the study}

The study is amongst a few research efforts attempting to explore the drivers of choice of nature of alliance and further competitiveness of the alliance (Sklavounos and Hajidimitriou, 2014). For the academicians, this study explores the effect of different factors on the nature of alliance and its competitiveness through qualitative data and development of hierarchical modelling. This is approach to examine antecedents to a dependent factor is scantly used especially in alliance literature. Academicians need to look beyond empirical quantitative analysis-based models to examine the causation. Using qualitative data collected based on FGD, the study takes into account the practical realities of business world. This is of significance to practitioners as the subjective relevance of the antecedents are taken into 
in this study. Further, the hierarchical model provides the rank order of factors as per their significance on the nature of alliance and its competitiveness.

\section{Limitation and future research}

The limitation of the study is lack of empirical validation. The study has limitation on generalizability. This can be overcome by undertaking the study in a different context.

This study will shed light on the role played by coordination concerns when firms make decisions regarding alliances. It will distinguish appropriation needs from coordination needs. This study proposes that JV structures are preferred as a result. Also, the presence of a technological component in an alliance will have an important role in the nature of alliance. Our research will be able to analyse the nature of complexity and comes to the conclusion that various kinds of complexity does not lead to firms opting for JVs. Usually, firms prefer to take care of these complexities through contractual alliances, which is at odds with our hypothesis. This is in accordance with research done by Colombo in 2003. This opposite nature of firms can be credited to the fact that firms would be interdependent on each other cancelling out the need for a JV or equity structure. Research by Garcia-Canal, 1996 states that alliances formed for pure technological activities will be formulated through a contractual alliance and it is clear that transfer of technology does not affect equity stake according to our findings. Contractual alliances are easy to carry out in case of a specified time period for the alliance. This is in accordance with our research which states that JV structures are preferred in case of an open-ended alliance.

According to Zahra et al, 2000 firms which have previous occupancy in alliance country and operate in the same sector as that of the alliance will prefer a contractual alliance as it would cost the firm less. The firm already has knowledge of the environment of the alliance country and does not need a JV to safe guard itself.

\section{Conclusion}

Our research does not take into account alternatives to forming alliances. By participating in networks (Gulati, 1998; Ahuja, 2000) or using physical co-location (Zucker, Darby and Armstrong) firms can obtain the same benefits they would have gotten through alliances. This does not limit our research as firms choose between forming an alliance or its alternatives beforehand and our research starts after they have made this decision. We do not measure appropriation and coordination concerns directly but through circumstantial factors alliance nature. Hence a partner firm might get rid of appropriation through the right contractual clause and hence opt for CA. We have focused on equity investment at the time alliance was announced and not examined its evolution. Therefore, the study contains limitations which can lead to more research. There can be several extensions to our study. Our study can be expanded to different industries, compared with the results of acquisitions or a more detailed analysis of only one factor can be done.

Our research has important connotations for managers as it provides information as to when an expensive JV structure can be avoided. These circumstances include when the nature of the alliance is strategically simple but technologically simple, countries have identical IPPR regimes, firm has previous occupancy in alliance country, or it operates in the alliance industry. If these circumstances do not present themselves then a JV structure is required to fulfil coordination and control needs and make for a successful partnership.

\section{References}

Ahuja, G. (2000) 'The Duality of Collaboration: Inducements and Opportunities in the Formation of Interfirm Linkages', Strategic Management Journal, 21(3, Special Issue: Strategic Networks), pp. 317-343.

Bakker, R. M. and Knoben, J. (2014) 'Built to Last or Meant to End: Intertemporal Choice in Strategic Alliance Portfolios', Organization Science, 26(1), pp. 256-276. doi: 10.1287/orsc.2014.0903.

Balakrishnan, S. and Koza, M. P. (1993) 'Information asymmetry, adverse selection and joint ventures: Theory and evidence', Journal of Economic Behavior and Organization, 20(January 1993), pp. 99-117.

Bamel, N., Dhir, S. and Sushil (2019) 'Inter-partner dynamics and joint venture competitiveness: a fuzzy TISM approach', Benchmarking. doi: 10.1108/BIJ-02-2018-0041.

Barringer, B. R. and Harrison, J. S. (2000) 'Walking a tightrope: Creating value through interorganizational relationships', Journal of Management, 26(3), pp. 367-403.

Benbya, H. and McKelvey, B. (2006) 'Toward a complexity theory of information systems development', Information 
Technology and People, 19(1), pp. 12-34.

Borys, B. and Jemison, D. B. (1989) 'Hybrid Arrangements as Strategic Alliances: Theoretical Issues in Organizational Combinations', The Academy of Management Review, 14(2), pp. 234-249.

Buckley, P. J. and Cason, M. (2016) The future of the multinational enterprise. Springer.

Chung, C. C. and Beamish, P. W. (2010) 'The Trap of Continual Ownership Change in International Equity Joint Ventures', Organization Science, 21(5), pp. 995-1015.

Colombo, M. G. (2003) 'Alliance form: A test of the contractual and competence perspectives', Strategic Management Journal, 24(12), pp. 1209-1229.

Contractor, F. J. (1989) 'Inter-Firm technology transfers and the theory of multinational enterprise', The International Trade Journal, 4(1), pp. 21-48.

Culpan, R. (2009) 'A fresh look at strategic alliances: research issues and future directions', International Journal of Strategic Business Alliances, 1(1), pp. 4-23.

Dan, S. M. and Zondag, M. M. (2016) 'Drivers of alliance terminations: An empirical examination of the biopharmaceutical industry', Industrial Marketing Management. Elsevier Inc., 54, pp. 107-115.

Das, T. K. and Teng, B. (2000a) 'A Resource-Based Theory of Strategic Alliances', Journal of Management, 26(1), pp. 3161.

Das, T. K. and Teng, B. (2000b) 'Instabilities of Strategic Alliances: An Internal Tensions Perspective', Organization Science, 11(1), pp. 77-101.

Dasgupta, N. (2000) 'Environmental enforcement and small industries in India: Reworking the problem in the poverty context', World Development, 28(5), pp. 945-967.

Delios, A. and Beamish, P. W. (2001) 'Survival and Profitability: The Roles of Experience and Intangible Assets in Foreign Subsidiary Performance', Academy of Management Journal, 44(5), pp. 1028-1038.

Dhir, S. et al. (2019) 'Integration of knowledge and enhancing competitiveness: A case of acquisition of Zain by Bharti Airtel', Journal of Business Research. Elsevier. doi: 10.1016/j.jbusres.2019.02.056.

Dhir, S. and Dhir, S. (2018) 'Role of Ambidexterity and Learning Capability in Firm Performance: A study of Ecommerce industry in India', VINE Journal of Information and Knowledge Management Systems, 48(4), pp. 517-546.

Dhir, S., Dhir, S. and Samanta, P. (2018) 'Defining and developing a scale to measure strategic thinking', Foresight, 20(3), pp. 271-288.

Dhir, S. and Mital, A. (2013a) 'Asymmetric motives in Indian bilateral cross-border joint ventures with G7 nations: impact of relative partner characteristics and initial conditions', International Journal of Strategic Business Alliances, 3(1), pp. 69-92.

Dhir, S. and Mital, A. (2013b) 'Value Creation on Bilateral Cross-Border Joint Ventures: Evidence from India.', Strategic Change, 22(5/6), pp. 307-326.

Dhir, S. and Mital, A. (2018) 'An explorative study of trends, distribution and pattern of bilateral cross-border joint ventures (CBJVs)', Journal of Indian Business Research.

Dhir, S., Mital, A. and Srivastava, S. K. (2015) 'Dynamics of Value Creation in Indian Bilateral Cross-Border Joint Ventures: A Systems Approach', Strategic Change, 22, pp. 471-483.

Dhir, S. and Sushil (2017) 'Flexibility in Modification and Termination of Cross-Border Joint Ventures', Global Journal of Flexible Systems Management. Springer India, 18(2), pp. 139-151.

Dikova, D. and van Witteloostuijn, A. (2007) 'Foreign direct investment mode choice: entry and establishment modes in transition economies', Journal of International Business Studies, 38(6), pp. 1013-1033.

Doz, Y. L. and Hamel, G. (1998) The Alliance Advantage: The Art of Creating Value through Partnership. Boston: Harvard Business Press.

Dubey, R. et al. (2015) 'Building theory of sustainable manufacturing using total interpretive structural modelling', International Journal of Systems Science: Operations \& Logistics, 2(4), pp. 231-247.

Dubey, R. et al. (2017) 'Sustainable supply chain management: framework and further research directions', Journal of Cleaner Production. Elsevier Ltd, 142, pp. 1119-1130.

Dussauge, P., Garrette, B. and Mitchell, W. (2004) 'Asymmetric performance: The market share impact of scale and link alliances in the global auto industry', Strategic Management Journal, 25(7), pp. 701-711.

Glaister, K. W. (1998) 'Strategic Motives for UK International Alliance Formation', in International Strategic Management and Government Policy. London: Palgrave Macmillan UK, pp. 40-77.

Grant, R. M. and Baden-Fuller, C. (2004) 'A Knowledge Accessing Theory of Strategic Alliances', Journal of Management Studies, 41(1), pp. 61-84.

Gulati, R. (1998) 'Alliances and Networks', Strategic Management Journal, 19(4, Special Issue: Editor's Choice), pp. 293317.

Gulati, R., Lavie, D. and Singh, H. (2009) 'The Nature of Partnering Experience and the Gains from Alliances', Strategic Management Journal, 30(11), pp. 1213-1233.

Gulati, R., Nohria, N. and Zaheer, A. (2000) 'Strategic Networks', Strategic Management Journal, 21(3), pp. $203-215$. 
Gulati, R. and Singh, H. (1998) 'The Architecture of Cooperation: Managing Coordination Costs and Appropriation Concerns in Strategic Alliances', Administrative Science Quarterly, 43(4), pp. 781-814.

Haleem, A. et al. (2012) 'Analysis of critical success factors of world-class manufacturing practices: An application of interpretative structural modelling and interpretative ranking process', Production Planning and Control, 23(1011), pp. 722-734.

Hamilton, B. A. and Nickerson, J. A. (2003) 'Correcting for Endogeneity in Strategic Management Research', Strategic Organization, 1(1), pp. 51-78.

Harrigan, K. R. (1985) 'Coalition Strategies : A Framework for Joint Ventures ”, Academy of Management Proceedings.

Harrigan, K. R. (1988) 'Joint Ventures and Competitive Strategy', Strategic Management Journal, 9(2), pp. 141-158.

Hasan, Z., Dhir, S. and Dhir, S. (2019) 'Modified total interpretive structural modelling (TISM) of asymmetric motives and its drivers in Indian bilateral CBJV', Benchmarking: An International Journal, p. BIJ-01-2018-0020. doi: 10.1108/BIJ-01-2018-0020.

Heimeriks, K. H. and Duysters, G. (2007) 'Alliance capability as a mediator between experience and alliance performance: An empirical investigation into the alliance capability development process', Journal of Management Studies, 44(1), pp. 25-49.

Hennart, J.-F., Dong-Jae Kim and Zeng, M. (1998) 'The Impact of Joint Venture Status on the Longevity of Japanese Stakes in U.S. Manufacturing Affiliates', Organization Science, 9(3), pp. 382-395.

Hitt, M. A. et al. (2004) 'The Institutional Effects on Strategic Alliance Partner Selection in Transition Economies: China vs. Russia', Organization Science, 15(2), pp. 173-185.

Inkpen, A. C. and Currall, S. C. (2004) 'The Coevolution of Trust, Control, and Learning in Joint Ventures', Organization Science, 15(5), pp. 586-599. doi: 10.1287/orsc.

Kale, P., Dyer, J. H. and Singh, H. (2002) 'Alliance Capability, Stock Market Response, and Long-Term Alliance Success: The Role of the Alliance Function', Strategic Management Journal, 23(8), pp. 747-767.

Kale, P. and Singh, H. (2009) 'Managing Strategic Alliances: What Do We Know Now, and Where Do We Go From Here?', The Academy of Management Perspectives, 23(3), pp. 45-62.

Kogut, B. (1988) 'Joint ventures: Theoretical and Empirical Perspectives', Strategic Management Journal, 9(4), pp. 319332.

Kogut, B. and Singh, H. (1988) 'The Effect of National Culture on the Choice of Entry Mode', Journal of International Business Studies, 19(3), pp. 411-432.

$\mathrm{Ku}$, K. C., Gurumurthy, C. K. and Kao, H.-P. (2007) 'Inter-firms Collaboration of Joint Venture in IC Foundry Business', Technovation, 27(5), pp. 296-305.

Kumar, N. (1995) 'Industrialisation, Liberalisation and Two Way Flows of Foreign Direct Investments Case of India', Economic and Political Weekly, 30(50), pp. 3228-3237.

Lavie, D. and Rosenkopf, L. (2006) 'Balancing Exploration and Exploitation in Alliance Formation', Academy of Management Journal, 49(4), pp. 797-818.

Luo, Y. (1997) 'Partner Selection and Venturing Success: The Case of Joint Ventures with Firms in the People's Republic of China', Organization Science, 8(6), pp. 648-662.

Luo, Y. and Tung, R. L. (2007) 'International expansion of emerging market: A springboard perspective', Journal of International Business Studies, 38(4), pp. 481-498.

Madhok, A. (1997) 'Cost, Value and Foreign Market Entry Mode: the Transaction and the Firm', Strategic Management Journal, 18(1), pp. 39-61.

Madhok, A. (2006) 'How Much Does Ownership Really Matter? Equity and Trust Relations in Joint Venture Relationships', Journal of International Business Studies, 37(1), pp. 4-11.

Makino, S. et al. (2007) 'Intended and Unintended Termination of International Joint Ventures', Strategic Management Journal, 28(11), pp. 1113-1132.

Makino, S., Lau, C. and Yeh, R. (2002) 'Asset-Exploitation versus Asset-Seeking: Implications for Location Choice of Foreign Direct Investment from Newly Industrialized Economies', Journal of International Business Studies, 33(3), pp. 403-421.

Makino, S. and Neupert, K. E. (2000) 'National Culture, Transaction Costs, and the Choice between Joint Venture and Wholly Owned Subsidiary', Journal of International Business Studies, 31(4), pp. 705-713.

Mesquita, L. F. and Brush, T. H. (2008) 'Untangling Safeguard and Production Coordination Effects in Long-Term Buyer-Supplier Relationships.', Academy of Management Journal, 51(4), pp. 785-807.

Meyer, K. E. et al. (2009) 'Institutions, resources, and entry strategies in emerging economies', Strategic Management Journal, 30(1), pp. 61-80.

Mohr, A. T. and Puck, J. (2013) 'Revisiting the Trust-performance Link in Strategic Alliances', Management International Review, 53(2), pp. 269-289.

Morschett, D., Schramm-Klein, H. and Swoboda, B. (2010) 'Decades of research on market entry modes: What do we really know about external antecedents of entry mode choice?', Journal of International Management. Elsevier 
Inc., 16(1), pp. 60-77.

Oxley, J. E. and Sampson, R. C. (2004) 'The Scope and Governance of International R\&D Alliances', Strategic Management Journal, 25749, pp. 723-749.

Pan, Y. and Tse, D. K. (2000) 'The Hierarchical Model of Market Entry Modes', Journal of International Business Studies, 31(4), pp. 535-554.

Parameswar, N. and Dhir, S. (2018a) 'Post termination interaction in international joint ventures (IJV)', Foresight, 21(2), pp. 200-215. doi: https:// doi.org/10.1108/FS-03-2018-0022.

Parameswar, N. and Dhir, S. (2018b) 'Technology Transfer and Innovation in Global International Joint Venture (IJV) - Emerging Markets Perspective', in Connell, J. et al. (eds) Global Value Chains, Flexibility and Sustainability, pp. 77-87.

Parameswar, N. and Dhir, S. (2019) 'Global marketplace strategy and choice of interaction after termination of international joint venture', Strategic Change, 28(3), pp. 177-184. doi: 10.1002/jsc.2260.

Parameswar, N., Dhir, S. and Ongsakul, V. (2018) 'Purpose of international joint venture and interaction post termination', Journal of Global Business Advancement, 11(6), pp. 687-705.

Park, S. H. and Russo, M. V (1996) 'When Competition Eclipses Cooperation: An Event History Analysis of Joint Venture Failure', Management Science, 42(6), pp. 875-890.

Park, S. H. and Ungson, G. R. (1997) 'The Effect of National Culture, Organizational Complementarity, and Economic Motivation on Joint Venture Dissolution', Academy of Management Journal, 40(2, Special Research Forum on Alliances and Networks), pp. 279-307.

Parkhe, A. (1993) 'Strategic Alliance Structuring: A Game Theoretic and Transaction Cost Examination of Interfirm Cooperation', Academy of Management Journal, 36(4), pp. 794-829.

Pfeffer, J. and Nowak, P. (1976) 'Joint Ventures and Interorganizational Interdependence', Administrative Science Quarterly, 21(3), pp. 398-418.

Reuer, J. J. and Ariño, A. (2007) 'Strategic alliance contracts: Dimensions and determinants of contractual complexity', Strategic Management Journal, 28(3), pp. 313-330.

Reuer, J. J., Zollo, M. and Singh, H. (2002) 'Post-Formation Dynamics in Strategic Alliances', Strategic Management Journal, 23(2), pp. 135-151.

Reus, T. and Rottig, D. (2009) 'Meta-analyses of international joint venture performance determinants: Evidence for theory, methodological artifacts and the unique context of China', Management International Review, 49(5), pp. 607-640.

Rothaermel, F. T. and Deeds, D. L. (2004) 'Exploration and exploitation alliances in biotechnology: a system of new product development', Strategic Management Journal, 25(3), pp. 201-221.

Rothaermel, F. T. and Deeds, D. L. (2006) 'Alliance type, alliance experience and alliance management capability in high-technology ventures', Journal of Business Venturing, 21(4), pp. 429-460.

Rudy, B. C., Miller, S. R. and Wang, D. (2016) 'Revisiting FDI Strategies and the Flow of Firm-Specific Advantages: A Focus on State-Owned Enterprises', Global Strategy Journal, 6(1), pp. 69-78.

Rugman, A. M. and Verbeke, A. (2003) 'Extending the theory of the multinational enterprise: Internalization and strategic management perspectives', Journal of International Business Studies, 34(2 Focused Issue: The Future of Multinational Enterprise: 25 Years Later), pp. 125-137.

Saggi, K. (2002) 'Trade, Foreign Direct Investment, and International Technology Transfer: A Survey', The World Bank Research Observer, 17(2), pp. 191-235.

Shibin, K. T. et al. (2018) 'Frugal innovation for supply chain sustainability in SMEs: multi-method research design', Production Planning and Control. Taylor \& Francis, 29(11), pp. 908-927.

Shrotriya, S., Sushil and Dhir, S. (2017) 'Strategic Change and Flexibility in the Operations of a Large Public-Sector Enterprise', Global Journal of Business Excellence, 10(1), pp. 9-17.

Shukla, D. M. and Mital, A. (2016) 'Effect of firm's diverse experiences on its alliance portfolio diversity: Evidence from India', Journal of Management and Organization, pp. 1-25.

Singh, A. K. and Sushil (2013) 'Modeling enablers of TQM to improve airline performance', International Journal of Productivity and Performance Management, 62(3), pp. 250-275.

Sklavounos, N. and Hajidimitriou, Y. A. (2014) 'Revisiting Trust at the Later Stages of International Joint Ventures: The role of Longevity , Interdependence and Risk of Opportunism', Journal of Economics and Business, 17(2), pp. 119-132.

Stuart, T. E. (2000) 'Interorgainzational Alliances and the Performance of Firms: A Study of Growth and Innovation Rates in a High-Technology Industry', Strategic Management Journal, 21(8), pp. 791-811.

Sushil (2017a) 'Modified ISM/TISM Process with Simultaneous Transitivity Checks for Reduced Direct Pair Comparisons', Global Journal of Flexible Systems Management, 18(4), pp. 331-351.

Sushil (2017b) 'Multi-criteria valuation of flexibility initiatives using integrated TISM - IRP with a big data framework', Production Planning \& Control. Taylor \& Francis, 28(11-12), pp. 999-1010. 
Tomkins, C. (2001) 'Interdependencies, trust and information in relationships, alliances and networks', Accounting, Organizations and Society, 26(2), pp. 161-191.

Turowski, D. (2005) 'The Decline and Fall of Joint Ventures: How JVs Became Unpopular and Why That Could Change', Journal of Applied Corporate Finance, 17(2), pp. 82-86.

Wang, J.-Y. and Blomstrom, M. (1992) 'Foreign Investment and Technology Transfer: A simple Model', European Economic Review, 36(1), pp. 137-155.

Warfield, J. N. (1974) 'Toward Interpretation of Complex Structural Models', IEEE Transactions on Systems, Man, and Cybernetics, 5, pp. 405-417.

Yadav, N., Sushil and Sagar, M. (2015) 'Modeling strategic performance management of automobile manufacturing enterprises: An Indian context', Journal of Modelling in Management, 10(2), pp. 198-225.

Yu, J., Lee, S. H. and Han, K. (2015) 'FDI motives, market governance, and ownership choice of MNEs: A study of Malaysia and Thailand from an incomplete contracting perspective', Asia Pacific Journal of Management, 32(2), pp. 335-362.

\section{Exhibit 1- Interpretive logic - knowledge base}

\begin{tabular}{|c|c|c|c|c|c|}
\hline $\begin{array}{c}\text { S. } \\
\text { No }\end{array}$ & $\begin{array}{c}\text { Element } \\
\text { codes }\end{array}$ & Pairwise comparison & $\mathrm{Y} / \mathrm{N}$ & Interpretation & Reference \\
\hline 1 & C1-C6 & $\begin{array}{l}\text { Internal coordination } \\
\text { will enhance the } \\
\text { competitiveness of JV }\end{array}$ & Y & $\begin{array}{l}\text { Helps to achieve target and there is effective } \\
\text { exchange of attitude and information }\end{array}$ & $\begin{array}{l}\text { Kale et al., 2002; Luo and } \\
\text { Tung, 2007; Park and } \\
\text { Ungson, } 1997\end{array}$ \\
\hline 2 & $\mathrm{C} 2-\mathrm{C} 1$ & $\begin{array}{c}\text { Internal complexity } \\
\text { will influence Internal } \\
\text { coordination }\end{array}$ & Y & $\begin{array}{l}\text { It reflects willingness, mutual trust, } \\
\text { judgement, management style and methods of } \\
\text { communication between the partner firm }\end{array}$ & $\begin{array}{l}\text { Das and Teng, 2000; Lavie } \\
\text { and Rosenkopf, } 2006\end{array}$ \\
\hline 3 & C2-C5 & $\begin{array}{l}\text { Internal complexity } \\
\text { will influence nature } \\
\text { of alliance }\end{array}$ & $\mathrm{Y}$ & $\begin{array}{c}\text { Bring higher transaction risk and affect } \\
\text { decision making process to organizations and } \\
\text { alliance }\end{array}$ & $\begin{array}{l}\text { Reuer et al., 2002; Tomkins, } \\
2001\end{array}$ \\
\hline 4 & C2-C6 & $\begin{array}{l}\text { Internal complexity } \\
\text { will influence } \\
\text { competitiveness of JV }\end{array}$ & Y & Transitive & \\
\hline 5 & $\mathrm{C} 2-\mathrm{C} 7$ & $\begin{array}{l}\text { Internal complexity } \\
\text { will influence number } \\
\text { of existing alliances }\end{array}$ & $\mathrm{Y}$ & $\begin{array}{l}\text { The partner tends to become distrustful and it } \\
\text { leads to malfunction of existing alliance }\end{array}$ & Park and Ungson, 1997 \\
\hline 6 & C3-C2 & $\begin{array}{c}\text { Strategic specification } \\
\text { will influence Internal } \\
\text { complexity }\end{array}$ & Y & $\begin{array}{l}\text { Specification in strategy is required to identify } \\
\text { the employee needs, analyse the knowledge } \\
\text { gaps within the partner firms }\end{array}$ & $\begin{array}{c}\text { Benbya and McKelvey, } \\
\text { 2006; Borys and Jemison, } \\
1989 \\
\end{array}$ \\
\hline 7 & C3-C7 & $\begin{array}{l}\text { Strategic specification } \\
\text { will influence number } \\
\text { of existing alliances }\end{array}$ & Y & $\begin{array}{l}\text { Strategic specification is necessary for } \\
\text { improving management practices and } \\
\text { coordination between sponsoring firm }\end{array}$ & Stuart, 2000; Yu et al., 2015 \\
\hline 8 & C4-C6 & $\begin{array}{l}\text { Prior presence of the } \\
\text { company will } \\
\text { influence } \\
\text { competitiveness of JV }\end{array}$ & Y & $\begin{array}{c}\text { Prior presence of the company helps in terms } \\
\text { of experience, assets, consumer base, market, } \\
\text { knowledge and skills to better manage the } \\
\text { alliance }\end{array}$ & $\begin{array}{l}\text { Delios and Beamish, 2001; } \\
\text { Park and Russo, } 1996\end{array}$ \\
\hline 9 & C5-C1 & $\begin{array}{l}\text { Nature of alliance will } \\
\text { influence Internal } \\
\text { coordination }\end{array}$ & $\mathrm{Y}$ & $\begin{array}{c}\text { Difference in management style, operation, } \\
\text { technology and resources affects coordination } \\
\text { among partner firms }\end{array}$ & Gulati et al., 2000 \\
\hline 10 & C5-C4 & $\begin{array}{l}\text { Nature of alliance will } \\
\text { influence prior } \\
\text { presence of the } \\
\text { company }\end{array}$ & $\mathrm{Y}$ & $\begin{array}{l}\text { Diverse resources, skills, managerial } \\
\text { interaction and characteristic of alliance } \\
\text { affects the prior presence of the firm }\end{array}$ & $\begin{array}{l}\text { Kale, Dyer \& Singh, 2002; } \\
\text { Heimeriks \& Duysters, } \\
2007\end{array}$ \\
\hline 11 & C5-C6 & $\begin{array}{l}\text { Nature of alliance will } \\
\text { influence } \\
\text { competitiveness of JV }\end{array}$ & $\mathrm{Y}$ & Transitive & \\
\hline 12 & C7-C2 & $\begin{array}{l}\text { Number of existing } \\
\text { alliances will } \\
\text { influence internal } \\
\text { complexity }\end{array}$ & $\mathrm{Y}$ & $\begin{array}{l}\text { New knowledge, techniques, cultural } \\
\text { difference and knowledge gap increases the } \\
\text { chance of conflicts }\end{array}$ & Gulati et al., 2000 \\
\hline 13 & C7-C4 & $\begin{array}{l}\text { Number of existing } \\
\text { alliances will } \\
\text { influence prior } \\
\text { presence of the } \\
\text { company }\end{array}$ & Y & $\begin{array}{c}\text { Share experiences, resources, know-how and } \\
\text { consumer base helps to easily gain market } \\
\text { access }\end{array}$ & $\begin{array}{l}\text { Heimeriks and Duysters, } \\
2007\end{array}$ \\
\hline
\end{tabular}

www.jbrmr.com A Journal of the Academy of Business and Retail Management (ABRM) 


\begin{tabular}{|c|c|c|c|c|c|}
\hline 14 & C7-C5 & $\begin{array}{l}\text { Number of existing } \\
\text { alliances will } \\
\text { influence nature of } \\
\text { alliance }\end{array}$ & Y & $\begin{array}{c}\text { New set of alliance and partners have } \\
\text { different objectives, techniques, agreements } \\
\text { and market }\end{array}$ & Dussauge et al., 2004 \\
\hline 15 & C7-C6 & $\begin{array}{l}\text { Number of existing } \\
\text { alliances will } \\
\text { influence } \\
\text { competitiveness of JV }\end{array}$ & Y & Transitive & \\
\hline 16 & $\mathrm{C} 8-\mathrm{C} 2$ & $\begin{array}{l}\text { Industry type will } \\
\text { influence internal } \\
\text { complexity }\end{array}$ & Y & Transitive & \\
\hline 17 & $\mathrm{C} 8-\mathrm{C} 3$ & $\begin{array}{c}\text { Industry type will } \\
\text { influence strategic } \\
\text { specification }\end{array}$ & $\mathrm{Y}$ & $\begin{array}{c}\text { Supports the degree of firm's } \\
\text { interdependence and competitive actions to } \\
\text { select a business strategy }\end{array}$ & $\begin{array}{l}\text { Das and Teng, 2000b; Hitt } \\
\text { et al., } 2004\end{array}$ \\
\hline 18 & $\mathrm{C} 8-\mathrm{C} 7$ & $\begin{array}{l}\text { Industry type will } \\
\text { influence number of } \\
\text { existing alliances }\end{array}$ & $\mathrm{Y}$ & Transitive & \\
\hline
\end{tabular}

Exhibit 2 - Reachability matrix

\begin{tabular}{|c|c|c|c|c|c|c|c|c|}
\hline Elements & C1 & C2 & C3 & C4 & C5 & C6 & C7 & C8 \\
\hline C1 & 1 & 0 & 0 & 0 & 0 & 1 & 0 & 0 \\
\hline C2 & 1 & 1 & 0 & 0 & 1 & $1^{*}$ & 1 & 0 \\
\hline C3 & 0 & 1 & 1 & 0 & 0 & 0 & 1 & 0 \\
\hline C4 & 0 & 0 & 0 & 1 & 0 & 1 & 0 & 0 \\
\hline C5 & 1 & 0 & 0 & 1 & 1 & $1^{*}$ & 0 & 0 \\
\hline C6 & 0 & 0 & 0 & 0 & 0 & 1 & 0 & 0 \\
\hline C7 & 0 & 1 & 0 & 1 & 1 & $1^{*}$ & 1 & 0 \\
\hline C8 & 0 & $1^{*}$ & 1 & 0 & 0 & 0 & $1^{*}$ & 1 \\
\hline
\end{tabular}

Exhibit 3- Partitioning the Reachability matrix into different levels and Final

\begin{tabular}{|c|c|c|c|c|}
\hline Elements & Reachability Set & Antecedent Set & Intersection Set & Level \\
\hline \multicolumn{5}{|c|}{ (a): Iteration-1 } \\
\hline $\mathrm{C} 1$ & 16 & 125 & 1 & \\
\hline $\mathrm{C} 2$ & 12567 & 2378 & 2 & \\
\hline $\mathrm{C} 3$ & 237 & 38 & 3 & \\
\hline $\mathrm{C} 4$ & 46 & 457 & 4 & \\
\hline C5 & 1456 & 257 & 5 & \\
\hline C6 & 6 & 124567 & 6 & 1 \\
\hline C7 & 24567 & 2378 & 27 & \\
\hline $\mathrm{C} 8$ & 2378 & 8 & 8 & \\
\hline \multicolumn{5}{|c|}{ (b): Iteration-2 } \\
\hline $\mathrm{C1}$ & 1 & 125 & 1 & II \\
\hline $\mathrm{C} 2$ & 1257 & 2378 & 27 & \\
\hline $\mathrm{C} 3$ & 237 & 38 & 3 & \\
\hline $\mathrm{C4}$ & 4 & 457 & 4 & II \\
\hline $\mathrm{C} 5$ & 145 & 257 & 5 & \\
\hline $\mathrm{C} 7$ & 2457 & 2378 & 27 & \\
\hline $\mathrm{C} 8$ & 2378 & 8 & 8 & \\
\hline \multicolumn{5}{|c|}{ (c): Iteration-3 } \\
\hline $\mathrm{C} 2$ & 257 & 2378 & 27 & \\
\hline $\mathrm{C} 3$ & 237 & 38 & 3 & \\
\hline C5 & 5 & 257 & 5 & III \\
\hline C7 & 257 & 2378 & 27 & \\
\hline $\mathrm{C} 8$ & 2378 & 8 & 8 & \\
\hline \multicolumn{5}{|c|}{ (c): Iteration-4 } \\
\hline $\mathrm{C} 2$ & 27 & 2378 & 27 & IV \\
\hline $\mathrm{C} 3$ & 237 & 38 & 3 & \\
\hline C7 & 27 & 2378 & 27 & IV \\
\hline $\mathrm{C} 8$ & 2378 & 8 & 8 & \\
\hline
\end{tabular}




\begin{tabular}{|c|c|c|c|c|}
\hline C3 & $\mathbf{3}$ & $\mathbf{3 8}$ & $\mathbf{3}$ & V \\
\hline C8 & 38 & 8 & 8 & \\
\hline (c): Iteration-6 & 8 & 8 & 8 & VI \\
\hline C8 & 8 & & 8 & \\
\hline
\end{tabular}

\begin{tabular}{|c|c|l|c|}
\hline S. No. & Element Codes & \multicolumn{1}{|c|}{ Elements } & Level in the TISM \\
\hline 1 & C6 & Competitiveness of JV or Contractual Agreement & I \\
\hline 2 & C1 & Internal Coordination & II \\
\hline 3 & C4 & Prior Presence of the Company & II \\
\hline 4 & C5 & Nature of Alliance & III \\
\hline 5 & C2 & Internal Complexity & IV \\
\hline 6 & C7 & No of existing alliance & IV \\
\hline 7 & C3 & Strategic Specification & V \\
\hline 8 & C 8 & Industry Type & VI \\
\hline
\end{tabular}

The boldtext specifies variables selected at different levels 
Exhibit 4 - Diagraph after hierarchical partitioning with the polarity of links (ISM)

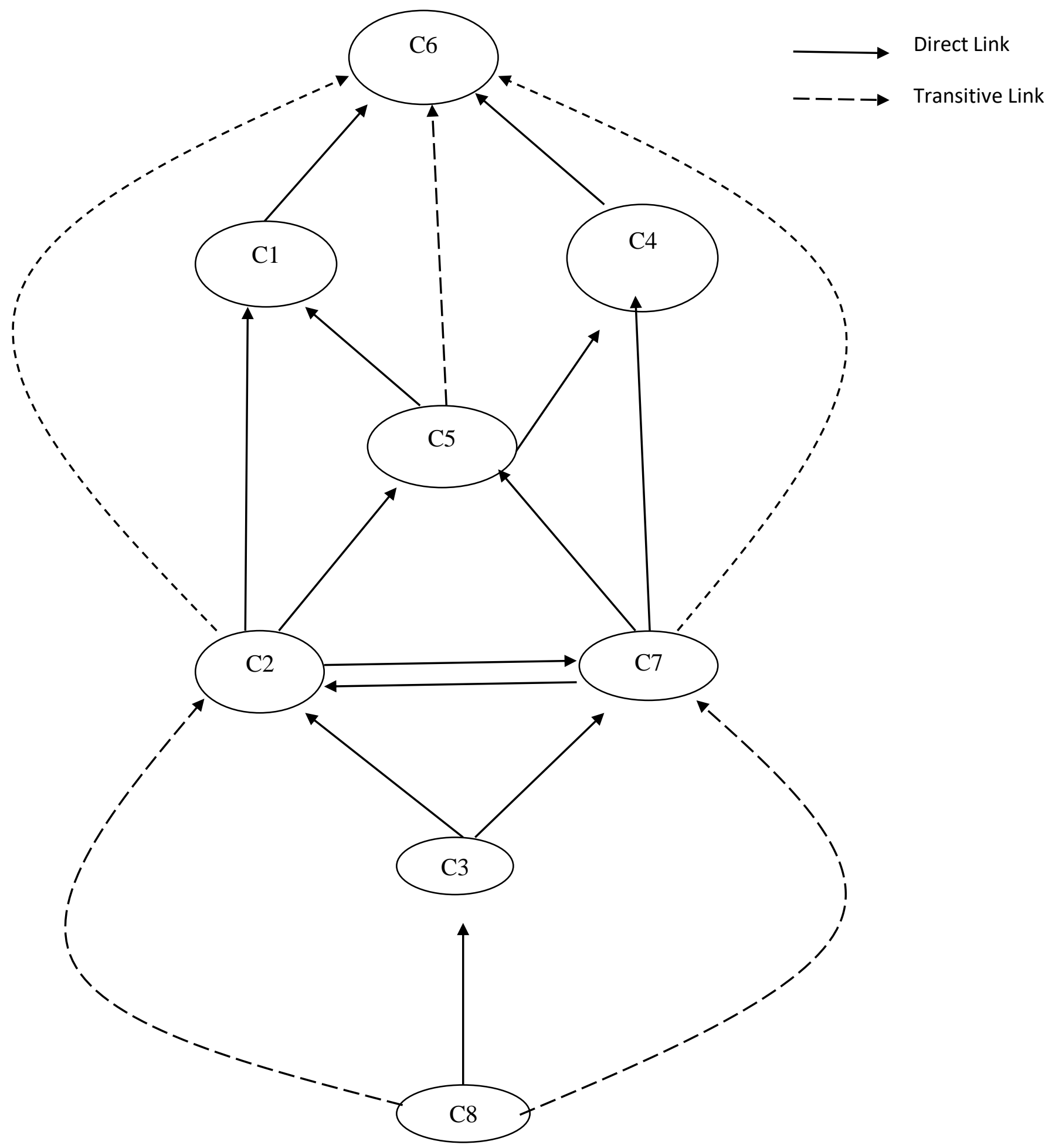




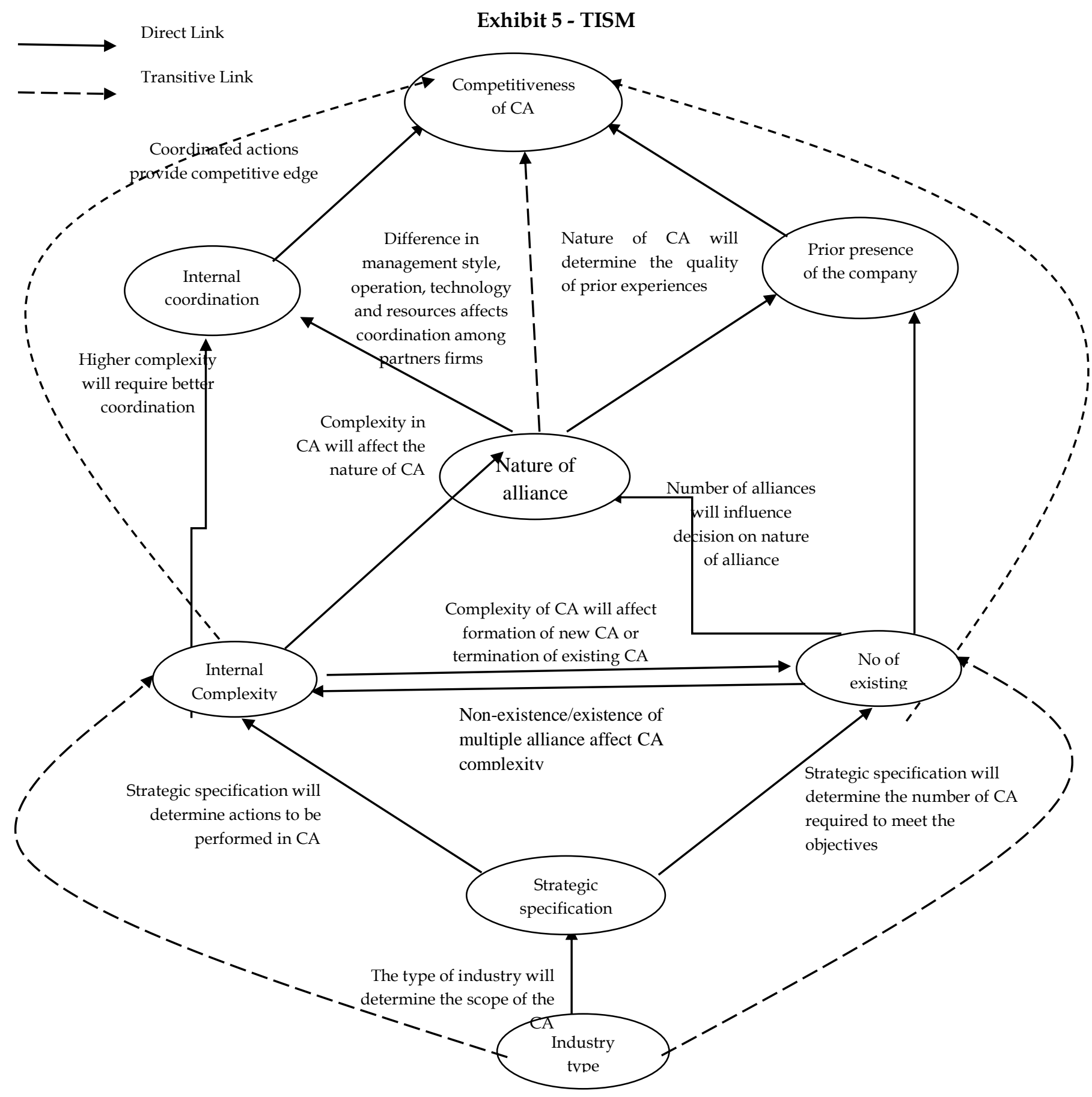

